\title{
Oncocytic neoplasms; rare adrenocortical tumours - a report of eleven patients
}

\author{
Nowotwory onkocytarne, rzadkie guzy kory nadnerczy — prezentacja \\ jedenastu chorych
}

\author{
Hande Peynirci', Bengür Taskıran², Nagehan Dik ${ }^{3}$, Özlem Saraydaroğlư ${ }^{4}$, Canan Ersoy ${ }^{5}$ \\ ${ }^{1}$ Department of Internal Medicine, Division of Endocrinology and Metabolism, Kastamonu State Hospital, Kastamonu, Turkey \\ ${ }^{2}$ Department of Internal Medicine, Division of Endocrinology and Metabolism, Yunus Emre State Hospital, Eskisehir, Turkey \\ ${ }^{3}$ Department of Internal Medicine, Bursa State Hospital, Bursa, Turkey \\ ${ }^{4}$ Department of Pathology, Uludag University Faculty of Medicine, Bursa, Turkey \\ ${ }^{5}$ Department of Internal Medicine, Division of Endocrinology and Metabolism, Uludag University Faculty of Medicine, Bursa, \\ Turkey
}

\begin{abstract}
Introduction: Oncocytomas of adrenal glands are extremely rare and usually present as incidentally detected masses. We aimed to present a series of patients with adrenal oncocytomas and review the literature.

Material and methods: Electronic database of patients with adrenal tumours, who were admitted to the internal medicine and endocrinology and metabolism outpatient clinics of Uludag University Medical Faculty between January 2005 and November 2016, were assessed retrospectively. Those who underwent surgery and pathological diagnosis of oncocytoma $(n=11)$ were included to the study. The demographic, clinical, pathological, radiological, and laboratory features were evaluated.

Results: Of these 11 patients, $54.5 \%(n=6)$ were female and $45.5 \%(n=5)$ were male. They aged between 31 and 76 years $(45.36 \pm 13.68)$. Five $(45.5 \%)$ of the masses showed endocrinological activity and were more frequent in women. The masses were 25-130 (57.63 \pm 34.04$)$ $\mathrm{mm}$ in width and 20-100 (47.82 \pm 28.95$) \mathrm{mm}$ in length. Seven $(63.6 \%)$ oncocytomas were classified as benign and the remainder as having uncertain malignant potential according to Lin-Weiss-Bisceglia criteria. Mean duration of follow-up were 24.8 (6-60) months and 38.2 (15-82) months, respectively.

Conclusions: Because there are no unique clinical and imaging characteristics differentiating adrenal oncocytomas from other types of adrenal masses, it should be kept in mind in differential diagnosis of adrenal masses, especially large ones and those suspicious for adrenocortical carcinoma. (Endokrynol Pol 2018; 69 (6): 682-687)
\end{abstract}

Key words: adrenal incidentaloma; adrenal oncocytoma; Cushing syndrome; Conn syndrome; undetermined malignant

\section{Streszczenie}

Wstęp: Onkocytoma nadnerczy to niezwykle rzadki nowotwór, zwykle wykrywany przypadkowo. Autorzy przedstawiają serię 11 przypadków chorych z guzem onkocytarnym nadnerczy oraz przegląd piśmiennictwa.

Materiał i metody: Oceniono retrospektywnie elektroniczną bazę danych pacjentów z guzami nadnerczy przyjętych do Kliniki Chorób Wewnętrznych oraz Kliniki Endokrynologicznej i Zaburzeń Metabolicznych Wydziału Medycznego Uniwersytetu w Uludag w okresie od stycznia 2005 do listopada 2016 roku. Do badania włączono osoby, u których wykonano zabieg chirurgiczny i na podstawie badania histopatologicznego rozpoznano onkocytoma $(\mathrm{n}=11)$. Przeanalizowano dane demograficzne, kliniczne, patologiczne, radiologiczne i laboratoryjne. Wyniki: Spośród tych 11 chorych kobiety stanowiły 54,5\% ( $=6)$, a mężczyźni 45,5\% ( $\mathrm{n}=5)$. Badani byli w wieku 31-76 lat $(45,36 \pm 13,68)$. Aktywność hormonalną stwierdzono w przypadku 5 guzów (45,5\%), hormonalnie czynne guzy występowały częściej u kobiet. Wymiary

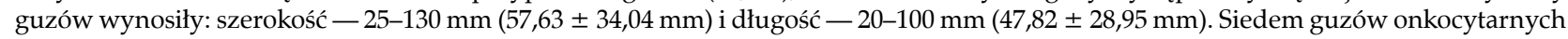
$(63,6 \%)$ sklasyfikowano jako łagodne, a pozostałe jako guzy o niepewnym potencjale złośliwości na podstawie kryteriów klasyfikacji Lin-Weiss-Bisceglia. Średni czas obserwacji wynosił odpowiednio 24,8 miesiąca (6-60 mies.) i 38,2 miesiąca (15-82 mies.).

Wnioski: Z uwagi na to, że nie ma szczególnych objawów klinicznych ani cech w badaniach obrazowych odróżniających nowotwory onkocytarne od innych guzów nadnerczy, należy pamiętać o tych guzach podczas diagnozy różnicowej masy wykrytej w nadnerczach, zwłaszcza jeśli jest ona duża i budzi podejrzenie raka kory nadnerczy. (Endokrynol Pol 2018; 69 (6): 682-687)

Słowa kluczowe: incidentaloma nadnerczy; onkocytoma nadnerczy; zespół Cushinga; zespót Conna; niepewny stopień złośliwości

\section{Introduction}

An adrenal mass that is detected incidentally on radiological evaluation of a patient without signs or symptoms attributable to adrenal disease is defined as an "adrenal incidentaloma". Most of the cases are non-functional adrenocortical adenomas. Adrenocortical carcinomas, cysts, ganglioneuromas, myelolipomas, haematomas, pheochromocytomas, and adrenal metastases are the other possible causes [1]. Oncocytoma 
is a rare aetiology of adrenal incidentaloma. The term "oncocyte" was first used by Hamperl to describe large granular cells with eosinophilic cytoplasm observed in Hurthle cell tumours of the thyroid gland [2]. In 1986, Kakimoto et al. reported a mass in the adrenal gland with a similar appearance to oncocytoma; however, the tumour was termed as adrenocortical adenoma due to lack of clear definition of adrenal oncocytoma (AO) [3]. In the same year, after confirmation by electron microscopy by Smirnova et al. [4], the term AO emerged. Oncocytomas are defined as neoplasms consisting of cells with an abundant amount of eosinophilic granular cytoplasm packed with swollen mitochondria and composed solely or mostly of oncocytes [5].

They are mostly localised in the adrenal cortex; rarely they have been detected in adrenal medulla or heterotopic adrenal tissue [6,7]. Neither environmental nor genetic risk factors were found so far for oncocytomas and they are usually incidentally detected [8]. Although the exact incidence is unknown, approximately 159 cases have been reported in the literature up to now [7]. Most of the literature on adrenal oncocytomas (AOs) focus on the clinical and pathologic features, and a limited number of them reveal the radiological findings. In this study, we aimed to present clinical, radiological, pathological, and immunohistochemical staining features of $11 \mathrm{AOs}$ and review the literature.

\section{Material and methods}

\section{Study population}

The study was approved by the Clinical Investigations Ethics Committee of Uludag University, Faculty of Medicine (Reference no: 2013-13/22). The patients who were followed up due to adrenal masses in internal medicine and endocrinology and metabolism outpatient clinics of Uludag University Medical Faculty between January 2005 and November 2016 were evaluated retrospectively. The inclusion criteria were age over 18 years, histopathological diagnosis of AOs after surgical resection, available data regarding hormonal assessment, and absence of any other malignancy.

\section{Study parameters}

Demographic and clinical data such as age, gender, signs and symptoms suggesting hormonal activity, and accompanying diseases including diabetes mellitus (DM), hypertension (HT), coronary artery disease (CAD), osteoporosis (OP), thyroid nodule, or hyperparathyroidism were recorded. Imaging characteristics such as localisation, size, adenomatoid component, presence of calcification, and hyperplasia were assessed using computerised tomography (CT) or magnetic resonance imaging (MRI). Lin-Weiss-Bisceglia criteria were used for histological subtype (9). Duration of follow-up was also noted.

\section{Biochemical and hormonal assessment}

Biochemical and endocrinological assessment included the following:

- serum fasting blood glucose, urea, creatinine, sodium, alanine aminotransferase, aspartate aminotransferase, complete blood count;

- serum adrenocorticotropic hormone (ACTH) and cortisol levels were measured at 08:00 a.m.;

- measurements of adrenaline, noradrenaline, metanephrine, normetanephrine, dopamine, and vanillylmandelic acid in 24-hour collected urine (one or more of them);

- plasma renin activity (PRA) and serum aldosterone level only in patients with hypertension;

- serum cortisol level after $1 \mathrm{mg}$ dexamethasone suppression test (DST) (1 mg dexamethasone was administered via oral route at 23:00 p.m., and fasting serum samples were collected at 08:00 a.m.);

- $2 \mathrm{mg}$ DST for two days in patients with serum cortisol levels not suppressed below $1.8 \mu \mathrm{g} / \mathrm{dl}$ after $1 \mathrm{mg}$ DST (dexamethasone $0.5 \mathrm{mg}$ tablet was given orally every six hours for two consecutive days and serum samples were collected at 08:00 a.m.);

- midnight serum cortisol level at 23:00 p.m.;

- cortisol measurement in 24-hour collected urine.

The patients with cortisol levels not suppressed below $1.8 \mu \mathrm{g} / \mathrm{dL}$ ( $50 \mathrm{nmol} / \mathrm{L}$ ) during 1 and $2 \mathrm{mg}$ DST, impaired diurnal rhythm, and low morning ACTH level without clinical manifestations of Cushing syndrome (CS) were considered to have subclinical CS. Patients with PRA less than $1 \mathrm{ng} / \mathrm{mL} /$ hour, plasma aldosterone level over $15 \mathrm{ng} / \mathrm{dL}$, and renin activity/aldosterone ratio (RAO) over 20 were further tested for hyperaldosteronism.

\section{Statistical analysis}

Statistical analysis was made using computer software SPSS version 16.0 (SPSS Inc. Chicago, IL, USA). Categorical variables were expressed as number and percentage (\%) and continuous variables were expressed as mean ( \pm standard deviation) and median (minimum-maximum).

\section{Results}

Out of 11 patients, $54.5 \%$ (n:6) were female and $45.5 \%$ (n: 5) were male. The patients were aged between 31 and $76(45.36 \pm 13.68)$ years. The mean ages of the female and male patients were $48.50 \pm 16.86$ and $41.60 \pm 8.96$ years, respectively. The masses were mostly detected during radiological investigation for vague abdominal pain, urological problems, or pulmonary 
Table I. Clinical characteristics of the patients and hormonal status of the masses

Tabela I. Charakterystyka kliniczna chorych i status hormonalny guzów

\begin{tabular}{llllll}
\hline Case & Age & Sex & Reason for applying & Accompanying illnesses & Diagnosis based on hormonal activity \\
\hline Case 1 & 31 & Female & $\begin{array}{l}\text { Weight gain, hirsutism, purple } \\
\text { striae, buffalo hump, moon face }\end{array}$ & HT + MNG & Cushing \\
\hline Case 2 & 32 & Male & Secondary HT workup & HT & Conn \\
\hline Case 3 & 35 & Male & Abdominal pain & None & Non-functional \\
\hline Case 4 & 35 & Female & Abdominal pain & None & Subclinical Cushing \\
\hline Case 5 & 39 & Male & Shortness of breath & Chronic bronchitis & Non-functional \\
\hline Case 6 & 39 & Female & Palpable mass & None & Non-functional \\
\hline Case 7 & 50 & Male & Intermittent urination & None & Non-functional \\
\hline Case 8 & 52 & Male & Side pain & None & Non-functional \\
\hline Case 9 & 54 & Female & Weight gain & DM2, HT, OP & Cushing \\
\hline Case 10 & 56 & Female & Abdominal pain & HT & Non-functional \\
\hline Case 11 & 76 & Female & Secondary HT workup & HT & Conn \\
\hline
\end{tabular}

HT - hypertension; MNG — multinodular goitre; DM2 — diabetes mellitus type 2; OP — osteoporosis

Table II. Radiological characteristics of oncocytomas

Tabela II. Charakterystyka radiologiczna nowotworów onkocytarnych

\begin{tabular}{|c|c|c|c|c|}
\hline Case & $\begin{array}{l}\text { Imaging } \\
\text { method }\end{array}$ & Side & Mass size & Radiological characteristics \\
\hline Case 1 & CT & Left & $30 \times 25 \mathrm{~mm}$ & Densely stained, ovoid, homogeneous solid lesion with regular margins (HU: 7) \\
\hline Case 2 & MRI & Left & $62 \times 56 \mathrm{~mm}$ & $\begin{array}{l}\text { Lesion with regular margins, isointense to liver, significant signal drop-off on out-of- } \\
\text { phase images due to the high lipid content }\end{array}$ \\
\hline Case 3 & MRI & Right & $72 \times 69 \mathrm{~mm}$ & $\begin{array}{l}\text { Lesion containing cystic foci with the biggest one being approximately } 1 \mathrm{~cm} \text {, absence of } \\
\text { signal drop-off on out-of-phase images due to the poor lipid content }\end{array}$ \\
\hline Case 4 & CT & Right & $35 \times 35 \mathrm{~mm}$ & Solid lesion containing millimetric calcification \\
\hline Case 5 & MRI & Left & $108 \times 96 \mathrm{~mm}$ & $\begin{array}{l}\text { Lesion with solid appearance, containing small cystic components from place to place, } \\
\text { heterogeneous enhancement after contrast administration, absence of signal drop-off on } \\
\text { out-of-phase images due to the poor lipid content }\end{array}$ \\
\hline Case 6 & СТ & Left & $130 \times 100 \mathrm{~mm}$ & Lesion containing necrotic areas (HU: 43) \\
\hline Case 7 & MRI & Left & $50 \times 30 \mathrm{~mm}$ & $\begin{array}{l}\text { Ovoid non-adenomatous lesion containing cystic and necrotic areas, absence of signal } \\
\text { drop-off on out-of-phase images due to the poor lipid content }\end{array}$ \\
\hline Case 8 & CT & Bilateral & $46 \times 43 \mathrm{~mm}$ & Two lesions compatible with non-adenoma (HU: 29) \\
\hline Case 9 & MRI & Right & $50 \times 32 \mathrm{~mm}$ & $\begin{array}{l}\text { Non-adenomatous lesion, absence of signal drop-off on out-of-phase images due to the } \\
\text { poor lipid content }\end{array}$ \\
\hline Case 10 & MRI & Right & $25 \times 20 \mathrm{~mm}$ & $\begin{array}{l}\text { Non-adenomatous lesion, absence of signal drop-off on out-of-phase images due to the } \\
\text { poor lipid content }\end{array}$ \\
\hline Case 11 & CT & Right & $26 \times 20 \mathrm{~mm}$ & Round lesion with regular contours with a relative contrast wash-out 56\% \\
\hline
\end{tabular}

CT — computed tomography; MRI — magnetic resonance, HU — Hounsfield units

diseases. However, one patient underwent imaging due to left-sided abdominal palpable mass, and one patient was evaluated due to characteristic features of Cushing syndrome. Five $(45.5 \%)$ of the masses proved to be functional tumours and were more common in women. Clinical characteristics and hormonal evaluation of the patients are shown in Table I.
Five patients had CT and six had MR imaging of the abdomen. The masses were $25-130(57.63 \pm 34.04) \mathrm{mm}$ in width and 20-100 (47.82 \pm 28.95$) \mathrm{mm}$ in length. One patient had undergone right adrenalectomy in another health facility and benign $\mathrm{AO}$ had been diagnosed in 2009. He was admitted to our institution with recurrent mass on the left side. Therefore, this mass was consid- 
Table III. Pathological diagnoses, immunohistochemical examination, and follow-up periods of the patients Tabela III. Diagnoza histopatologiczna, badanie immunohistochemiczne i okresy obserwacji chorych

\begin{tabular}{llll}
\hline Case & Pathological diagnosis & Immunohistochemical examination & Follow-up period \\
\hline Case 1 & Benign & Not examined & 19 months \\
\hline Case 2 & Uncertain malignant potential & Synaptophysin (negative) Inhibin (weakly positive) & 15 months \\
\hline Case 3 & Benign & Not examined & 27 months \\
\hline Case 4 & Benign & Synaptophysin (weakly positive) Inhibin (positive) & 19 months \\
\hline Case 5 & Uncertain malignant potential & Synaptophysin (negative) Inhibin (negative) & 32 months \\
\hline Case 6 & Uncertain malignant potential & Synaptophysin (negative) Inhibin (positive) & 24 months \\
\hline Case 7 & Benign & Not examined & 6 months \\
\hline Case 8 & Uncertain malignant potential & Synaptophysin (positive) & 82 months \\
\hline Case 9 & & Inhibin (positive) & 60 months \\
\hline Case 10 & Benign & Not examined & 25 months \\
\hline Case 11 & Benign & Not examined & 18 months \\
\hline
\end{tabular}

ered to be bilateral. The radiological characteristics of the masses are shown in Table II.

The pathological and immuno-histochemical features are shown in Table 3. Immuno-histochemical profile was studied in five cases. Chromogranin A was negative and Melan-A was positive in all cases. The duration of follow-up was 6-82 months after surgery (mean 29.7 months) (Table III).

\section{Discussion}

Oncocytomas commonly occur in kidney, thyroid, parathyroid, salivary, and pituitary gland. They rarely originate from respiratory system, larynx, and choroid plexus [8]. Oncocytomas of adrenal glands are extremely rare.

It has been reported to occur at any age without a certain age distribution (mean age at diagnosis is 47 years, ranging from 27 to 72 years) [8]. Also, there are case reports in childhood [10]. Our patients were aged between 31 and 76 years $(45.36 \pm 13.68)$, compatible with the literature. AOs have a female preponderance with a ratio of 2.5:1 in the literature [8]. We did not observe a prominent gender preponderance (1.19:1) in concordance with the report (1.8:1) by Wong et al. [11]. Nearly half of our patients had HT $(n=5)$. Two had hyperaldosteronism and two had Cushing syndrome, which may contribute to HT. Only one had non-functional AO. The patient with subclinical Cushing syndrome also did not have HT. These findings suggest a close relation between overt hormone secretion and HT in cases with AOs. On the other hand, another comorbidity accompanying functional adrenal tumours is DM, which was rarely encountered in our series (only one patient with Cushing syndrome).
AOs are mostly detected incidentally and $17 \%$ of them have been reported to be hormonally active [8]. Since the first description of AOs by Kakimoto et al., 49 hormone-secreting cases were published in the literature [12]. AOs secreting androgen, cortisol, and aldosterone together or individually have been reported. Also, there are case reports regarding interleukin-6 producing AOs [13]. It has been shown that patients may present with pseudo-precocious puberty and virilisation due to the androgen hypersecretion [8, 14]. Another clinical presentation is Cushing syndrome, and approximately 6 cases were published in the literature [12]. In our study, two patients were diagnosed with Cushing syndrome, and only one of them had typical Cushing stigmata. To the best of our knowledge, there is only one case report presenting with subclinical Cushing syndrome associated with AO. One of our patients had subclinical Cushing syndrome [15]. Although very rare, aldosterone-secreting AOs have also been reported [16]. Two of our patients were diagnosed with hyperaldosteronism during workup for secondary hypertension. Five masses $(45.5 \%)$ were found to be functional, similarly to past studies but in line with the data from a study done by Wong et al., which reported the hormonal activity as 54\% [11]. These findings suggest that AOs exert endocrinological activity more than previously thought.

AOs have a predilection for the left side, with a ratio of 2-3.5:1 [3, 17]. We did not detect a predilection for localisation. AOs were generally large in size. The size of the masses ranged from 30 to $150 \mathrm{~mm}$ with a mean of $80 \mathrm{~mm}[18,19]$. In our study the dimensions for width and length were $(25-130 \mathrm{~mm}, 57.63 \pm 34.04 \mathrm{~mm}$ and $20-100 \mathrm{~mm}, 47.82 \pm 28.95 \mathrm{~mm}$, respectively) 
similar to previous reports. In one of the largest studies regarding the imaging characteristics of AOs, the mean diameter of benign oncocytic tumours was $76 \mathrm{~mm}$, and the authors suggested that size criteria used for adrenal adenomas are not reliable for benign AOs [20]. While radiological characteristics for renal oncocytomas are well defined, there is no imaging characteristic for AOs. Central scarring at varying rates can be observed on CT or MR images; however, it is not a reliable indicator of differentiating benign AOs from malignant ones and oncocytomas from other adrenal masses $[7,8,20]$. We observed some imaging characteristics compatible with pheochromocytomas and adrenocortical carcinomas.

AOs and other adrenal masses are treated in the same way, taking functional status and radiological characteristics into consideration for surgery. All of the $\mathrm{AO}$ cases in the literature have been diagnosed retrospectively because there are no definite clinical or radiological features to discriminate preoperatively.

According to the current classification system, AOs are divided into three histological categories: benign, uncertain malignant potential, and malignant. The histological scoring system for adrenocortical tumours was first introduced by Weiss [21]. Recently, Bisceglia et al. recommended a scoring system consisting of major and minor criteria, especially to determine the histological extent of the AOs [9]. Three major criteria are high mitotic rate ( $>5$ mitosis in $50 \times$ magnification), atypical mitosis, and venous invasion. Four minor criteria include tumour measuring over $10 \mathrm{~cm}$ in diameter or weighing over $200 \mathrm{~g}$, tumour necrosis, and capsular and sinusoidal invasion. The presence of one major criteria confirms malignancy, 1-4 minor criteria indicate uncertain malignant potential, and absence of major and minor criteria suggest benignity [9]. Seven of 11 patients were classified as benign and the remaining as uncertain malignant potential $(63.6 \%$ and $36.4 \%$, respectively), according to the Lin-Weiss-Bisceglia criteria in our study. In a review of the pathologic features of 147 cases, approximately $80 \%$ of cases were reported to have benign or low malignancy potential [8]. To the best of our knowledge, there were 47 cases with uncertain malignant potential in the literature [11].

Determining the immunohistochemical profile of AOs is difficult because immunohistochemical examination was not performed and same staining pattern was not used in all cases. In challenging situations, immunohistochemical examinations aid in differentiating adrenocortical tumours from the medullary ones. They are generally negative for $\mathrm{S} 100$ and chromogranin and positive for melan-A [8, 22, 23]. Inhibin is generally positive $[8,11,23,24]$. Low positivity rate has been reported for synaptophysin $[8,11,22]$. Although im- munoreactivity for vimentin is variable, diffuse positivity is evident in most cases $[8,11,14,22,24]$. Sangoi and McKenney compared 63 adrenocortical lesions with 35 pheochromocytomas using the usual stains (chromogranin, calretinin, inhibin, melan A, and synaptophysin) and novel (steroidogenic factor-1 [SF-1], microtubule-associated protein 2 , and mammalian achaete-scute homolog-1) antibodies. The adrenocortical tumours were $100 \%$ negative for chromogranin, $89 \%$ positive for calretinin, $86 \%$ positive for inhibin and melan-A, and $59 \%$ positive for synaptophysin. The authors concluded that chromogranin plus SF-1, calretinin, or inhibin improves diagnostic sensitivity and specificity [25]. In our study chromogranin-negative and melan-A-positive staining in all specimens support the previous reports.

Prognosis of AOs varies according to the histological subtype. Currently, there are no recommendations for follow-up of benign AOs. The follow-up duration ranges from six months to 37 months without any recurrence in current literature $[17,26]$. There was only one case which was initially reported as benign but diagnosed to be malignant $\mathrm{AO}$ after recurrence and re-examination of the original specimen [9]. We did not observe recurrence of disease during 6-60 (mean 24.8) months of follow-up in seven patients with benign AOs. Recurrence rates for AOs with uncertain malignant potential are variable. It was reported as $6 \%$ in a series of 47 patients during a mean follow-up of 96 months [11]. Bisceglia et al. reported no recurrence in four patients during a mean follow-up time of 38.7 (10-61) months [9]. Lin et al. also did not observe recurrence in two patients followed up for 12-19 (mean 15.5) months [22]. We followed up four patients with uncertain malignant potential for 15-82 (mean 38.25) months, similarly to the study by Bisceglia et al. [9]. Wong et al. showed that estimated total median survival period of malignant AOs was 58 months (95\% confidence interval 27.5-88.5 months), which was better than that of adrenocortical carcinomas [11]. We have no experience with malignant AOs.

\section{Conclusions}

AOs pose challenges during radiological and histological examinations. They usually occur in adults. They are frequently non-functional; however, half of them may present as hormone active tumours, as we have shown. CT or MRI features cannot conclusively differentiate AOs from other adrenal masses or benign AOS from malignant ones. We observed that AOs may reveal imaging features common with pheochromocytomas and adrenocortical carcinomas. They are usually benign, although those with uncertain malignant potential or malignancy may be evident. 
Therefore, because there is no clear evidence regarding the true potential of this tumour, long-term follow-up is recommended.

\section{Conflict of interest}

The authors declare that there is no conflict of interest regarding the publication of this paper.

\section{Funding}

This research did not receive any specific grant from funding agencies in the public, commercial, or not-for-profit sectors.

\section{References}

1. Mansmann G, Lau J, Balk E, et al. The clinically inapparent adrenal mass: update in diagnosis and management. Endocr Rev. 2004; 25(2): 309-340, doi: 10.1210/er.2002-0031, indexed in Pubmed: 15082524.

2. Hamperl H. Oncocytes and the so called hurthle cell tumor. Arch Pathol. 1950; 49: 563-570.

3. Kakimoto S, Yushita Y, Sanefuji T, et al. Non-hormonal adrenocortica adenoma with oncocytoma-like appearances. Hinyokika Kiyo. 1986; 32(5): 757-763, indexed in Pubmed: 3751804.

4. Smirnova EA, Mikhaîlov IG. [Electron microscopic characteristics of oncocytoma of the lung, small intestine and adrenal gland]. Arkh Patol. 1986; 48(6): 79-81, indexed in Pubmed: 3019283

5. Chang A, Harawi SJ. Oncocytes, oncocytosis, and oncocytic tumors. Pathol Annu. 1992; 27 Pt 1: 263-304, indexed in Pubmed: 1736246.

6. Chisté M, Poppiti RJ, Bianco FJ. Oncocytoma of the adrenal gland medulla. Ann Diagn Pathol. 2013; 17(1): 123-126, doi: 10.1016/j.anndiagpath.2011.07.002, indexed in Pubmed: 22056038

7. Godin K, Bang N, Tolkach Y. Case report: Heterotopic intrarenally located adrenocortical oncocytoma. F1000Res. 2014; 3: 73, doi: 10.12688/f1000research 3780.1, indexed in Pubmed: 25254096.

8. Mearini L, Del Sordo R, Costantini E, et al. Adrenal oncocytic neoplasm a systematic review. Urol Int. 2013; 91(2): 125-133, doi: 10.1159/000345141, indexed in Pubmed: 23147196.

9. Bisceglia M, Ludovico O, Di Mattia A, et al. Adrenocortical oncocytic tumors: report of 10 cases and review of the literature. Int J Surg Pathol. 2004; 12(3): 231-243, doi: 10.1177/106689690401200304, indexed in Pubmed: 15306935.

10. Gumy-Pause F, Bongiovanni M, Wildhaber B, et al. Adrenocortical oncocytoma in a child. Pediatr Blood Cancer. 2008; 50(3): 718-721, doi: 10.1002/pbc.21090, indexed in Pubmed: 17091483.

11. Wong DD, Spagnolo DV, Bisceglia M, et al. Oncocytic adrenocortical neoplasms - a clinicopathologic study of 13 new cases emphasizing the importance of their recognition. Hum Pathol. 2011; 42(4): 489-499, doi: 10.1016/j.humpath.2010.08.010, indexed in Pubmed: 21237489.
12. Tartaglia N, Cianci P, Altamura A, et al. A Rare Case of Functioning Adrenocortical Oncocytoma Presenting as Cushing Syndrome. Case Rep Surg. 2016; 2016: 8964070, doi: 10.1155/2016/8964070, indexed in Pubmed: 26989553.

13. Kawahara Y, Morimoto A, Onoue A, et al. Persistent fever and weight loss due to an interleukin-6-producing adrenocortical oncocytoma in a girl--review of the literature. Eur J Pediatr. 2014; 173(8): 1107-1110, doi: 10.1007/s00431-014-2292-8, indexed in Pubmed: 24610396.

14. Sahin SB, Yucel AF, Bedir R, et al. Testosterone- and cortisol-secreting adrenocortical oncocytoma: an unusual cause of hirsutism. Case Rep Endocrinol. 2014; 2014: 206890, doi: 10.1155/2014/206890, indexed in Pubmed: 24716005

15. Lee SS, Baek KH, Lee YS, et al. Subclinical Cushing's syndrome associated with an adrenocortical oncocytoma. J Endocrinol Invest. 2008, 31(7): 675-679, doi: 10.1007/BF03345624, indexed in Pubmed: 18787391.

16. Terui K, Sakihara S, Kageyama K, et al. A case of adrenocortical oncocytoma occurring with aldosteronoma. J Clin Endocrinol Metab. 2010; 95(8): 3597-3598, doi: 10.1210/jc.2009-2787, indexed in Pubmed: 20685888.

17. Sharma N, Dogra PN, Mathur S. Functional adrenal oncocytoma: a rare neoplasm. Indian J Pathol Microbiol. 2008; 51(4): 531-533, indexed in Pubmed: 19008586

18. Shenouda M, Brown LG, Denning KL, et al. A Case of Oncocytic Adrenocortical Neoplasm of Borderline (Uncertain) Malignant Potential Cureus. 2016; 8(6): e638, doi: 10.7759/cureus.638, indexed in Pubmed: 27433417.

19. Ahmed MA, Sureshkannan KS, Raouf ZR, et al. Adrenal oncocytic neoplasm with uncertain malignant potential. Sultan Qaboos Univ Med J. 2013; 13(2): E334-E338, indexed in Pubmed: 23862048

20. Tirkes T, Gokaslan T, McCrea J, et al. Oncocytic neoplasms of the adrenal gland. AJR Am J Roentgenol. 2011; 196(3): 592-596, doi 10.2214/AJR.10.5212, indexed in Pubmed: 21343501.

21. Medeiros LJ, Weiss LM. New developments in the pathologic diagnosis of adrenal cortical neoplasms. A review. Am J Clin Pathol. 1992; 97(1) 73-83, indexed in Pubmed: 1728867.

22. Lin BT, Bonsib SM, Mierau GW, et al. Oncocytic adrenocortical neoplasms: a report of seven cases and review of the literature. Am J Surg Pathol. 1998; 22(5): 603-614, indexed in Pubmed: 9591731.

23. Surrey LF, Thaker AA, Zhang PJ, et al. Ectopic functioning adrenocortical oncocytic adenoma (oncocytoma) with myelolipoma causing virilization. Case Rep Pathol. 2012; 2012: 326418, doi: 10.1155/2012/326418, indexed in Pubmed: 23094172.

24. Song SY, Park S, Kim SR, et al. Oncocytic adrenocortical carcinomas: a pathological and immunohistochemical study of four cases in comparison with conventional adrenocortical carcinomas. Pathol Int. 2004; 54(8): 603-610, doi: 10.1111/j.1440-1827.2004.01669.x, indexed in Pubmed: 15260851

25. Sangoi AR, McKenney JK. A tissue microarray-based comparative analysis of novel and traditional immunohistochemical markers in the distinction between adrenal cortical lesions and pheochromocytoma. Am J Surg Pathol. 2010; 34(3): 423-432, doi: 10.1097/PAS.0b013e3181cfb506, indexed in Pubmed: 20154585.

26. Rutkowska J, Bandurska-Stankiewicz E, Kuglarz E, et al. Adrenocortical oncocytoma - a case report. Endokrynol Pol. 2012; 63(4): 308-311, indexed in Pubmed: 22933167. 